Rakenteiden Mekaniikka

Vol. 50, Nro 3, 2017, s. $118-121$

https://rakenteidenmekaniikka.journal.fi/index

https://doi.org/10.23998/rm.64954

(c)Kirjoittajat 2017.

Vapaasti saatavilla CC BY-SA 4.0 lisensioitu.

\title{
Kaksivaiheinen menettely epälineaarisen diskreetin teräsrakenteiden optimointitehtävän ratkaisemiseksi
}

\author{
Teemu Tiainen ${ }^{1}$ ja Kristo Mela
}

Tiivistelmä. Artikkelissa sovelletaan kaksivaiheista menettelyä diskreetin teräsrakenteen optimointiongelman ratkaisemiseen. Verrattuna paljolti kirjallisuudessa käytettyyn suoraan ratkaisumalliin laskentaesimerkissä päästään saman luokan tuloksiin, mutta merkittävästi lyhyemmässä ajassa. Laskentaesimerkkinä käytetään teräskehää, mutta menettely on periaatteessa yleinen ja sovellettavissa myös muihin optimoinnin aihealueisiin.

Avainsanat: diskreetti optimointi, teräskehän optimointi

Vastaanotettu 16.6.2017. Hyväksytty 1.7.2017. Julkaistu verkossa 21.8.2017

\section{Johdanto}

Yleensä kehämäisten rakenteiden suunnittelussa sauvojen profiilit valitaan kaupallisesti tarjolla olevasta valikoimasta. Näin ollen vastaava optimointiongelma on myös diskreetti. Kun otetaan lisäksi huomioon suunnittelustandardien [3, 4] laskentaohjeet, huomataan nopeasti käsillä olevan hyvin haastava epälineaarinen diskreetti ongelma. Tähän tehtävätyyppiin tarjotaan kirjallisuudessa ratkaisuksi lähinnä metaheuristisia menetelmiä, joista tunnetuimpia lienevät geneettiset algoritmit ja parveilualgoritmi. Menetelmiä on paljon ja esitetyt väitteet keskinäisestä paremmuudesta vaikuttaisivat olevan tehtävätyypistä riippuvaisia ja jossain määrin ristiriitaisia $[1,5,6]$. Myös kritiikkiä menetelmien hyvyydestä ja sen arvioinnista on esitetty [7]. Käytännön tehtävässä - vaikkapa suhteellisen rajatun tehtävän kuten ristikon - optimoinnissa vaadittava laskenta-aika monine ajoineen kasvaa helposti tunteihin [8]. Tämä on käytännön suunnittelutyössä liian pitkäksi koettu aika eikä pitkienkään ajojen jälkeen saadun tuloksen optimaalisuudesta ole takeita.

Diskreettiin tehtävään on suoran menettelyn sijaan kehitetty myös erilaisia kaksivaiheisia menettelyjä [2], joissa ensin relaksoidaan tehtävä jatkuvaksi, ratkaistaan jatkuva onglema, jonka jälkeen tarkastellaan jatkuvan ratkaisun diskreettiä ympäristöä ja pyritään ratkaisemaan tämä rajoitettu tehtävä. Tässä artikkelissa ehdotetaan tälle ajatukselle perustuvaa menettelyä, joka ei kuitenkaan aiemmasta kirjallisuudesta poiketen välttämättä

${ }^{1}$ Vastuullinen kirjoittaja. teemu.tiainen@tut.fi 


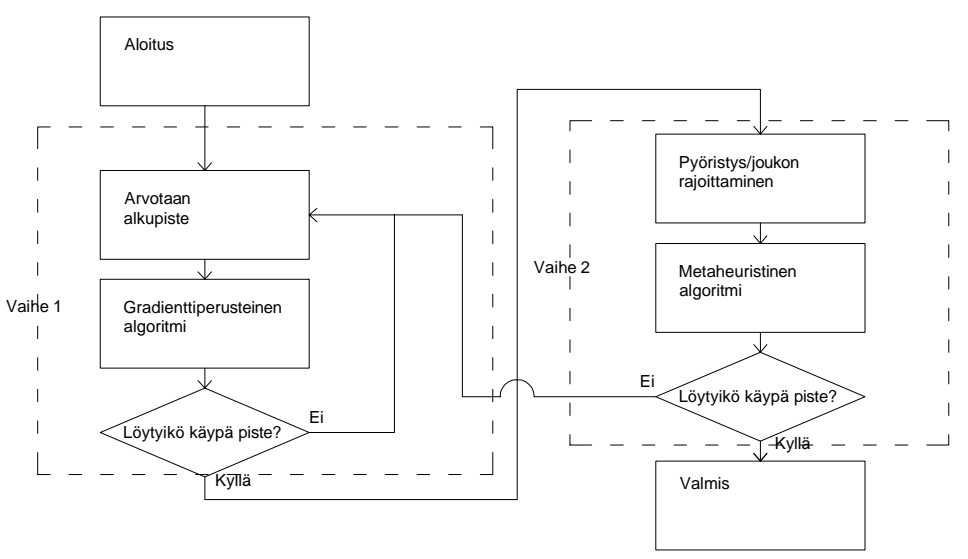

Kuva 1. Kaaviokuva ehdotetusta menettelystä.

vaadi tehtävälle tiettyä matemaattista muotoa mutta vaikuttaisi silti johtavan varsin hyviin tuloksiin.

\section{Ehdotettu menettely}

Sen sijaan, että suoraan lähdettäisiin ratkomaan täydellä suunnitteluavaruudella diskreettiä tehtävää, annetaan mitoitusmuuttujan olla jatkuva. Jos mitoitusmuuttujilla on selvästi tunnistettavissa usempia dimensioita kuin yksi, relaksoidussa tehtävässä voi olla myös useampi muuttuja kutakin alkuperäistä mitoitusmuuttujaa kohti. Jatkuvan tehtävän ratkaisemiseen on kirjallisuudessa tarjolla huomattava valikoima gradienttipohjaisia menetelmiä. Toisessa vaiheessa diskreettiä alkuperäistä suunnitteluavaruutta kavennetaan siten, että kullekin alkuperäisen tehtävän mitoitusmuuttujalle valitaan $n$ arvoa lähellä jatkuvan tehtävän ratkaisua ja etsitään parhaan kohdefunktion arvon antava yhdistelmä esimerkiksi metaheuristisella menetelmällä.

On otaksuttavaa, että johdannossa kuvailtu optimointiongelma on epäkonveksi. Jotta vältetään juuttuminen lokaaliin optimiin, olisi tehtävää ratkottava usealla alkupisteellä. Jotta voidaan käyttää arvottua alkupistettä, tulisi jatkuvan tehtävän algoritmin olla sellainen, joka sietää alkupisteen epäkäypyyden. Toisessa vaiheessa menetelmän tulee kyetä epälineaarisen diskreetin tehtävän ratkaisemiseen, mikä käytännössä rajaa ratkaisumenetelmän metaheuristisiin menetelmiin.

Menettelyssä on mahdollista käydä niin, että annetulla alkupisteellä jatkuva tehtävä ei konvergoi. Tällöin arvotaan uusi alkupiste. On niinikään mahdollista, että jatkuvan tehtävän ratkaisun lähiympäristön diskreetti hakuavaruus ei sisällä yhtään käypää ratkaisua. Myös tällöin arvotaan uusi alkupiste.

\section{Numeerinen esimerkki}

Tarkastellaan kuvan 2 tasoristikkoa, joka valmistetaan hitsaamalla teräksisistä kylmämuovatuista neliöputkiprofiileista. Kestävyyteen ja liitosten geometriaan liittyvät rajoitusehdot muodostetaan standardien EN 1993-1-1 ja EN 1993-1-8 mukaisesti. Tehtävänä on käyttäen SSAB:n profiilivalikoimaa (55 profiilivaihtoehtoa) etsiä kevein mahdollinen ristikko siten, että mainittujen standardien mitoitusehdot täyttyvät. Tarkemmin rajoitusehdot käydään läpi lähteessä [8]. Myös liitosten lokaali käsittely seuraa kyseistä lähdettä. Kuitenkin lähteestä poiketen solmupisteiden koordinaatit ja ristikon korkeus pidetään nyt 


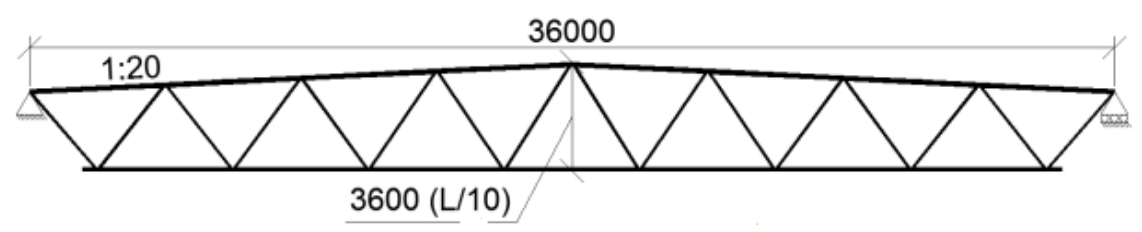

Kuva 2. Tarkasteltavan ristikon topologia ja mitat.

Taulukko 1. Laskentaesimerkin keskeiset tulokset.

\begin{tabular}{ccccccc}
\hline & \multicolumn{3}{c}{ Kohdefunktion arvo [kg] } & \multicolumn{2}{c}{ Funktioevaluoinnit [-] } \\
Menetelmä & Paras & Keskiarvo & Mediaani & Keskihajonta & Keskiarvo & Keskihajonta \\
\hline Suora GA & 1705 & 2504 & 2186 & 911 & 30753 & 1766 \\
2-vaiheinen & 1680 & 1833 & 1908 & 215 & 2758 & 1099 \\
\hline
\end{tabular}

vakioina eli kyseessä on mitoitusoptimointitehtävä. Ristikkoa kuormittaa yläpaarteella tasainen $25 \mathrm{kN} / \mathrm{m}$ kuorma.

Kaksivaiheisen menettelyn soveltamiseksi valitaan kunkin sauvan jatkuviksi muuttujiksi putken sivumitta $b$ ja seinämän paksuus $t$. Näiden muuttujien ala- ja ylärajat ovat valikoimasta löytyvät pienimmät ja suurimmat arvot. Poikkileikkaussuureet jatkuvaa tehtävää varten lasketaan standardin EN 10219-2 esittämällä tavalla.

Tehtävän kohdefunktio on valittujen jatkuvien muuttujien suhteen epälineaarinen, mutta jatkuva. Sen sijaan derivaatta seinämän paksuuden suhteen ei ole jatkuva. Sama pätee moniin rajoitusehtofunktioihin. Tästä huolimatta jatkuvan ongelman ratkaisuun käytetään Matlab-ohjelman 'active set' -menetelmää, joka on gradienttiperusteinen ja siten periaatteessa edellyttäisi derivoituvuutta. Kakkosvaiheen diskreetin ongelman ratkaisemiseen saman ohjelman geneettistä algoritmia. Kakkosvaiheen alussa käytetään läheisyyden mittana normeerattua euklidista etäisyyttä $(b, t)$-avaruudessa

$$
d_{j}=\sqrt{\left(\frac{b_{j}-b^{*}}{b_{\max }-b_{\min }}\right)^{2}+\left(\frac{t_{j}-t^{*}}{t_{\max }-t_{\min }}\right)^{2}}
$$

missä $b_{j}$ ja $t_{j}$ ovat vaihtoehdon $j$ dimensiot ja $b^{*}$ ja $t^{*}$ jatkuvan tehtävän ratkaisun dimensiot. Rajoitettuun hakuavaruuteen valitaan viisi lähintä profiilia.

Verrokkina samaa tehtävää ratkotaan suoraan diskreettinä ongelmana Matlabin geneettisellä algoritmilla, jolloin saadaan tietoa menetelmän tehokkuudesta. Valitettavasti kirjoittajien tiedossa ei ole kaikkien vaihtoehtojen (niitä on $55^{10}$ ) läpikäymisen lisäksi mitään menetelmää, jolla tehtävään saataisiin verrokkiratkaisuksi oikea globaali optimi, joten saadun ratkaisun optimaalisuudesta ei tällä koejärjestelyllä saada tietoa.

Koska molemmat menettelyt ovat stokastisia, on molempia syytä ajaa useita kertoja ja tuloksia tarkastella tilastollisin suurein. Tässä tapauksessa molempia menettelyitä on toistettu 50 kertaa. Keskeiset tulokset nähdään taulukossa 1.

Arvotulla alkupisteellä noin $65 \%$ tapauksista käy niin, ettei jatkuva tehtävä ratkea. Myös noin 24 \%:ssa tapauksista löytyneen jatkuvan tehtävän läheisyydestä muodostetun hakuavaruuden pisteistä ei löydy kohtuulliseksi arvioidun ajan kuluessa käypää. Huolimatta näistä seikoista menettely on keskimäärin nopea, joskin vaihtelu on edellä mainituista syistä suurehko. Paras löydetty käypä ratkaisu on kohdefunktion arvoltaan molemmilla menettelyillä samaa luokkaa. Kun ongelman suora ratkaiseminen geneettisellä 
algoritmilla vaatii noin kymmenkertaisen määrän funktioevaluointeja hajonnan ajojen tulosten välillä ollessa suurempi, voitaneen sanoa ehdotetun menettelyn olevan tuntuvasti tehokkaampi kuin suora geneettisen algoritmin soveltaminen.

\section{Päätelmät}

Käyttämällä kuvattua stokastista kaksivaiheista tekniikkaa optimoinnissa suoran metaheuristisen algoritmin soveltamisen sijaan päästään samaa luokkaa oleviin kohdefunktion arvoihin merkittävästi vähäisemmällä laskemisella. Lisäksi menettelyn tuottamien ratkaisuiden hajonta laskentaesimerkissä on huomattavasti alhaisempi kuin verrokkimenetelmällä tehdyissä koelaskelmissa. Tässä artikkelissa tuloksia on esitelty vain yhden esimerkin valossa, joten päätelmiä menetelmän yleiskäyttöisyydestä ei voitane tehdä, mutta jos ongelman relaksointi jatkuvaksi tehtäväksi on mahdollinen ja edelleen voidaan kehittää metriikka, jolla tunnistetaan lähimmät diskreetit suunnitteluavaruuden pisteet, menettelyn pitäisi sopia moniin muihinkin diskreetteihin ongelmiin myös kantavien rakenteiden optimoinnin ulkopuolella.

Kiitokset. Tekijät kiittävät Pirkanmaan Kultturirahastoa taloudellisesta tuesta.

\section{Viitteet}

[1] Ryan Alberdi and Kapil Khandelwal. Comparison of robustness of metaheuristic algorithms for steel frame optimization. Engineering Structures, 100:276-292, 2015. URL https:// doi.org/10.1016/j.engstruct.2015.06.014.

[2] Jasbir S. Arora and Min-Wei Huang. Discrete structural optimization with commercially available sections. J. Struct. Mech. Earthquake Eng., JSCE, 1996(549):1-18, 1996. URL https://doi.org/10.2208/jscej.1996.549_1.

[3] EN 1993-1-1. EN-1993-1-1. Eurocode 3: Design of steel structures. Part 1-1: General rules and rules for buildings. CEN, 2006.

[4] EN 1993-1-8. EN-1993-1-8. Eurocode 3: Design of steel structures. Part 1-8: Design of joints. CEN, 2006.

[5] O. Hasançebi, S. Çarbas, E. Dogăn, F. Erdal, and M.P. Saka. Comparison of nondeterministic search techniques in the optimum design of real size steel frames. Computers and Structures, 88:1033-1048, 2010. URL https://doi.org/10.1016/j.compstruc. 2010.06 .006 .

[6] Jussi Jalkanen. Tubular Truss Optimization Using Heuristic Algorithms. Phd thesis, Tampere University of Technology, 2007.

[7] Mathias Stolpe. Truss optimization with discrete design variables: a critical review. Structural and multi-disclipinary optimization, 53:349-374, 2015. URL https://doi.org/10.1007/ s00158-015-1333-x.

[8] Teemu Tiainen, Kristo Mela, Timo Jokinen, and Markku Heinisuo. The effect of steel grade in weight and cost of warren-type welded tubular trusses. Structures and buildings, pages -, 2017. accepted for publication.

Teemu Tiainen, Kristo Mela

PL 600, 33101 Tampere

s-posti: teemu.tiainen@tut.fi, kristo.mela@tut.fi 